\title{
Compositional methods for measuring fat components of the nutritional label of potato chips by visible and near-infrared spectroscopy
}

\author{
José Cayuela $^{1}$ and Elena Moriana-Correro ${ }^{2}$ \\ ${ }^{1}$ Instituto de la Grasa \\ ${ }^{2}$ University of Seville
}

May 8, 2020

\begin{abstract}
Commercial potato chips offer diverse compositions, while the nutritional label verification of chips batches by official methods is difficult. Thus, alternative technology is required. Nutritional label information is commonly provided as percentages of several nutritional categories. These correspond to data mathematically so-called compositional, for which specific statistical methods have been developed. Near-infrared spectroscopy is a rapid and non-destructive technique proven as useful in many different applications in the food industry. However, the need for the specific treatment of the compositional references used with NIRS methods has been considered, so far, in a few recent studies only. The present study proposes the methodology for measuring the nutritional label components of potato chips fat. Compositional calibration models based on visible and near-infrared spectroscopy were fitted by partial least squares. They were used to estimate the composition of saturated, monounsaturated, and polyunsaturated types of fat, as well as their total fat. This study proposes a useful compositional method for measuring the components of the potato chip's nutritional label or its verification.
\end{abstract}

\section{Hosted file}

Compositional methods for fat components of potato chips.edited.doc available at https: //authorea.com/users/319778/articles/449486-compositional-methods-for-measuring-fatcomponents-of-the-nutritional-label-of-potato-chips-by-visible-and-near-infraredspectroscopy

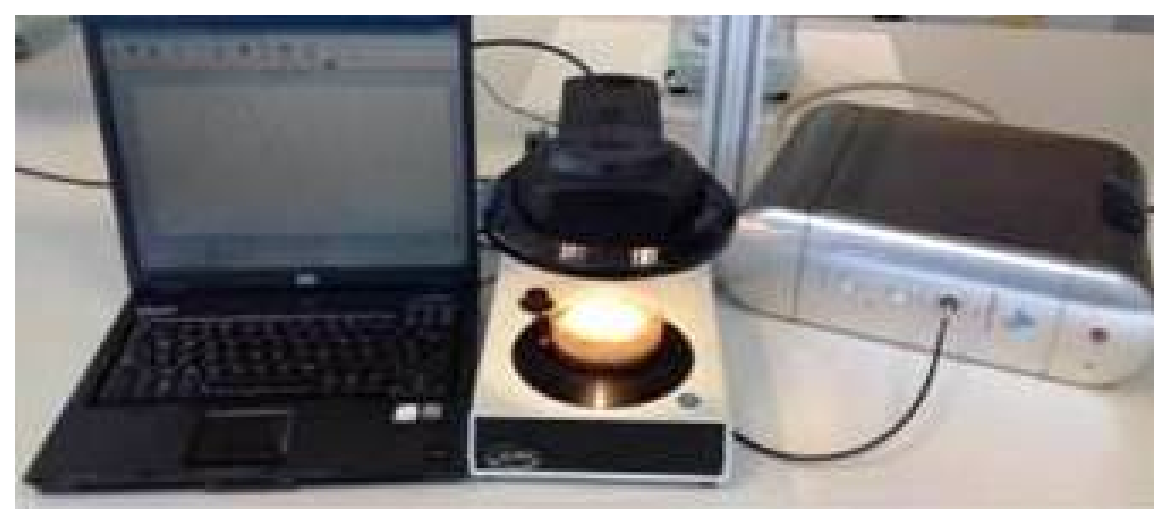



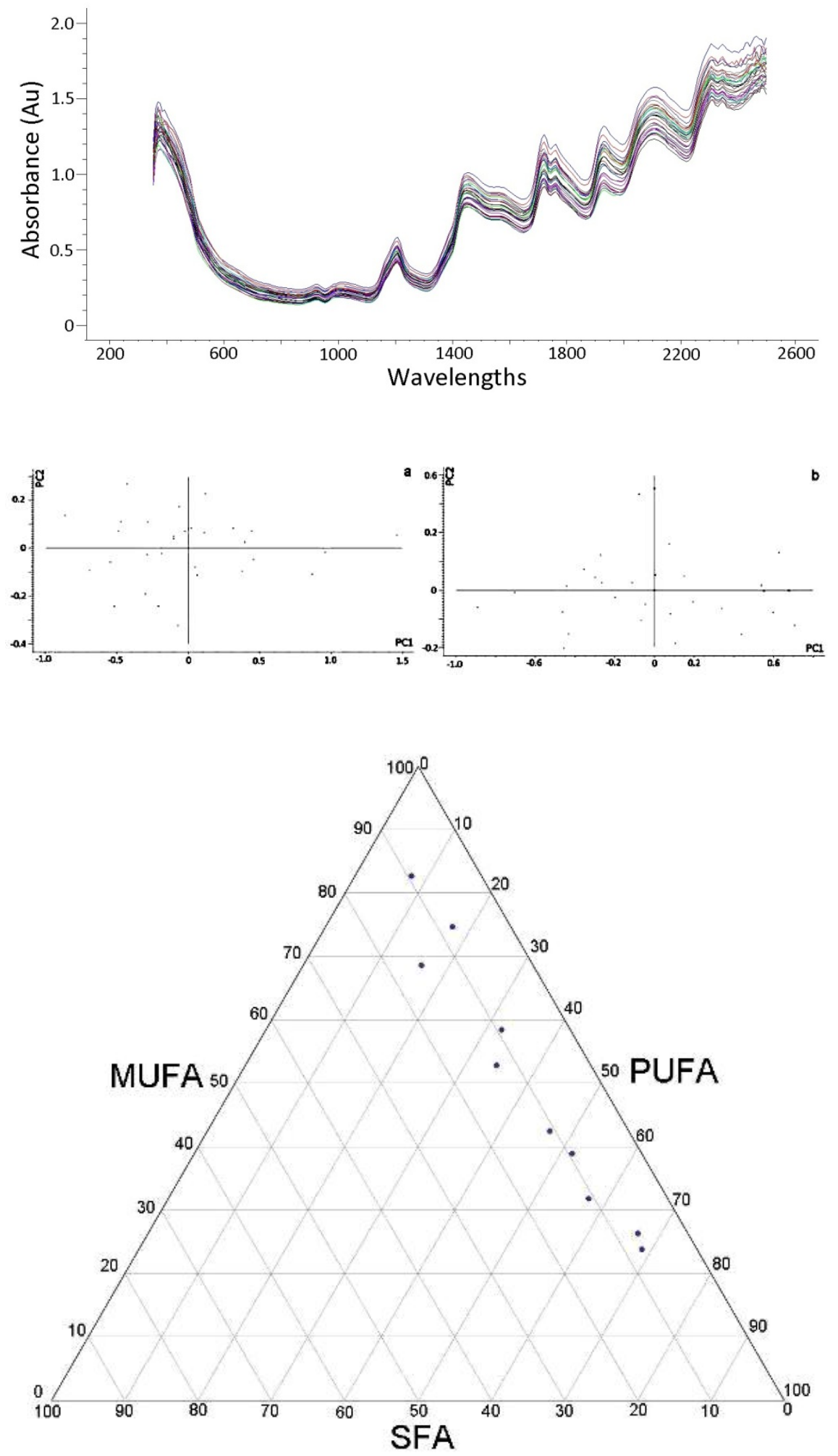

Hosted file 
Table 1.docx available at https://authorea.com/users/319778/articles/449486-compositionalmethods-for-measuring-fat-components-of-the-nutritional-label-of-potato-chips-byvisible-and-near-infrared-spectroscopy

\section{Hosted file}

Table 2.docx available at https://authorea.com/users/319778/articles/449486-compositionalmethods-for-measuring-fat-components-of-the-nutritional-label-of-potato-chips-byvisible-and-near-infrared-spectroscopy

\section{Hosted file}

Table 3.docx available at https://authorea.com/users/319778/articles/449486-compositionalmethods-for-measuring-fat-components-of-the-nutritional-label-of-potato-chips-byvisible-and-near-infrared-spectroscopy 